\title{
Urgences
}

\section{Toute la journée...}

\section{Danielle Grenier}

Numéro 15, octobre 1986

Épigraphiques

URI : https://id.erudit.org/iderudit/025348ar

DOI : https://doi.org/10.7202/025348ar

Aller au sommaire du numéro

Éditeur(s)

Urgences

ISSN

0226-9554 (imprimé)

1927-3924 (numérique)

Découvrir la revue

Citer ce document

Grenier, D. (1986). Toute la journée... Urgences, (15), 90-90.

https://doi.org/10.7202/025348ar

Ce document est protégé par la loi sur le droit d'auteur. L’utilisation des services d'Érudit (y compris la reproduction) est assujettie à sa politique d'utilisation que vous pouvez consulter en ligne.

https://apropos.erudit.org/fr/usagers/politique-dutilisation/
Cet article est diffusé et préservé par Érudit.

Érudit est un consortium interuniversitaire sans but lucratif composé de l’Université de Montréal, l'Université Laval et l'Université du Québec à Montréal. Il a pour mission la promotion et la valorisation de la recherche. https://www.erudit.org/fr/ 


\section{Danièle Grenier}

Les Dieux rendent fous ceux qu'ils aiment.

John Steinbeck: Tendre jeudi

Toute la journée, c'est de la mort qu'il avait parlé. Ses mots, dits avec nonchalance, elle les avait écoutés aisément. Sur la foi de leur enfance, elle avait écouté, avait aussi parlé, mais d'autre chose. Assurément de cette haie de rosiers sauvages, là-bas.

De lueur assassine dans ses yeux, aucune. De peur en elle, guère plus. Parfois une très légère angoisse. Guère plus. Il ne discourait pas sur la mort, ou à propos d'elle, n'en faisait pas le sujet de leur conversation. Seulement il n'arrivait pas à se détacher d'elle. Alors il l'évoquait. Il parlait, et elle voyait. Le voyait lui, à travers les images qu'il créait. Se voyait elle, dans la mort qui dévalait, qui emportait la haie de rosiers. La mort sauvage.

La journée durant, il avait parlé de la mort. La première image, celle d'une haie de rosiers sauvages. Et puis ses yeux à lui, l'herbe luisante, la falaise si magnifique, la mort qui glisse. Tout était si limpide.

Voyez-vous, cette journée-là, il parlait. De la mort. À vrai dire, il parlait de la mort sans arrêt. Et puis il y avait une haie. Des rosiers sauvages je crois. Elle écoutait, j'écoutais aussi, je crois. 